\title{
Karakuyu (Afyon) Gölü Sulak Alanı ve Çevresinin Hidrojeoloji İncelemesi
}

\author{
Şehnaz ŞENER*, Halime ÖZDEMIR
}

Süleyman Demirel Üniversitesi, Mühendislik Fakültesi, Jeoloji Mühendisliği Bölümü, Isparta, Türkiye

\begin{tabular}{ll}
\hline Anahtar Kelimeler & Öz \\
\hline Karakuyu Gölü, & Bu çalışmada, Karakuyu Gölü Sulak Alanı ve çevresinin jeolojik ve hidrojeolojik \\
Sulak alan, & özellikleri incelenmiştir. Ayrıca, çalışma alanındaki su kaynaklarının \\
Hidrojeoloji, & hidrojeokimyasal özellikleri, kullanılabilirliği ve kalite durumları belirlenmiştir. \\
Hidrojeokimya. & Bölgede Mesozoyik-Kuvaterner zaman aralığında farklı yaşve litolojiye sahip kaya \\
& birimleri yüzeylenmektedir. Çalışma alanında en önemli yüzey suları Karakuyu \\
& Gölü, Kumalar Çayı ve Eldere kaynağıdır. Bölgede maksimum yeraltısuyu derinliği \\
& 15.15 m olup yeraltısuyu akımı Karakuyu Gölü'ne doğrudur. Çalışma alanındaki su \\
& kaynaklarının hidrojeokimyasal özelliklerini belirlemek amaclyla, su örneklerinin \\
& kimyasal analizleri yapılmıștır. Elde edilen sonuçlara göre, suların tamamı Ca-HCO \\
& ve Ca-Mg-HCO ${ }_{3}^{\prime}$ lı sular fasiyesindedir. Su örnekleri genel olarak içme ve sulama \\
& suyu olarak kullanılabilir özellikte olup su kalite değerlendirme sonuçlarına göre \\
& sular çoğunlukla I. Su kalite sınıfında yer almaktadır.
\end{tabular}

\section{Investigation of Hydrogeological Properties of Karakuyu (Afyon) Lake Wetland and Its Surroundings}

\section{Keywords}

Karakuyu Lake,

Wetland,

Hydrogeology,

Hydrogeochemistry.

\begin{abstract}
In this study, geological and hydrogeological properties of the Karakuyu Lake wetland and its surroundings were investigated. In addition, the hydrogeochemical properties, availability and quality of the water resources have been determined in the study area. The rock units are observed with different age and lithology in the Mesozoic-Quaternary periods in the study area. The most important surface waters are Karakuyu Lake, Kumalar stream and Eldere spring. The maximum groundwater dept is determined as $15.15 \mathrm{~m}$ and groundwater flow direction is towards the Karakuyu Lake. In order to determine hydrogeochemical features of the water resources, chemical analyses of the water samples were performed. According to the obtained results, water resources are Ca-Mg- $\mathrm{HCO}_{3}$, Ca- $\mathrm{HCO}_{3}$ facies. In addition, all of the water samples can be used as drinking and irrigation water and the waters are in general water quality class I based on water quality assessments.
\end{abstract}

\footnotetext{
* ilgili yazar/ Corresponding Author: sehnazsener@sdu.edu.tr
} 


\section{Giriş}

İnsan yaşamının en temel gereksinimi olan suya olan ihtiyacın gün geçtikçe artması ve dünya üzerindeki su kaynaklarının hızla tüketilmesi ya da kullanılamaz hale gelmesi su kaynakları konusundaki araştırmaları daha önemli hale getirmiştir. Ülkemiz yüzey ve yer altısuları bakımından zengin bir ülke olmasına rağmen iklim değişiklikleri ve bilinçsiz kullanım miktar ve kalite açısından mevcut su kaynaklarımızı tehdit etmekledir.

En önemli su kaynaklarından biri olan sulak alanlar yeryüzünün en zengin ve üretken ekosistemleridir ve başta insanlar olmak üzere içerisindeki tüm canlılar için büyük önem taşımaktadırlar. Ramsar (1971)'a göre sulak alanlar; "alçak gelgitte derinliği 6 m'yi aşmayan deniz suyu alanlarını kapsamak üzere, doğal ya da yapay, sürekli ya da geçici, durgun ya da akar, tatlı, acı ya da tuzlu bütün sular ile bataklık, sazlık, ıslak çayırlar ve turbalıklar" olarak tanımlanmaktadır.

Sulak alanın su kütleleriyle bağlantısı kesilir, su rejimi bozulur veya ekolojik sağlığı bozulursa bu sulak alanın zarar görerek fonksiyonlarını yitirmesine sebep olmaktadır (Güney, 2014). Ülkemizdeki göller, akarsuların durgun akan kısımları, nehir deltaları, kıyı lagünleri, sazlıklar ve turbalıklar sulak alan tipleridir ve Ramsar Sözleşmesine göre Türkiye'de 135 adet uluslararası öneme sahip sulak alan bulunmaktadır. Ancak, bu alanlarda su rejimi etkileri, sanayi ve tarımın yarattığı kirlilik, aşırı ve kaçak avlanma gibi olumsuz etkiler sebebiyle ciddi problemler gözlenmektedir. Ayrıca, iklim değişikliğinin insanlar ve yaban hayatı üzerindeki etkilerinin artması, sulak alanları da olumsuz yönde etkilemektedir ve bu durum sulak alanların gelecek için korunması gerekli alanlar olduğunu ortaya koymaktadır.

Çalışma alanını oluşturan ve ülkemizin önemli sulak alanlarından biri olan Karakuyu Gölü sulak alanı Afyon ili-Dinar ilçe sınırları içerisinde yer almakta olup, batıda Büyük Menderes Havzasına, doğuda Uluborlu Ovasına, kuzeyde Ekin ovasına ve güneyde Burdur Havzasına komşudur. Karakuyu Gölü tektonik oluşumlu olup, bölgeyi etkileyen genç tektonik hareketler sonucu oluşmuş çöküntü alanlardır. Bölgedeki kontrolsüz atık yönetimi ve tarımsal kirlilik su kaynakları üzerinde tehdit oluşturmaktadır. Ayrıca, alanda torf alımı devam etmekte olup torf tesisinin sulak alana zarar verdiği gözlenmektedir. Bu çalışmada, Orman ve Su İşleri Bakanlığı tarafından 1994 yılında Yaban Hayatı Koruma Sahası olarak ilan edilmiş ve I. Derece Doğal Sit Alanı olan Karakuyu Gölü sulak alanı ve çevresinin hidrojeolojik ve hidrojeokimyasal incelemesi yapılmıştır.

\section{Bilimsel Yazın Taraması}

Tektonik bir oluşuma sahip olan çalışma alanı daha önce birçok araştırmacı tarafından jeolojik ve yapısal özellikleri yanı sıra jeomorfolojik, hidrografik ve ekolojik özellikleri bakımından incelenmiştir.

Karakuyu Gölü sulak alanı yaklaşık 10.99 km²'lik alan kaplamakta ve gölün su kotu 1005.57-1007.12 m arasında değişmektedir. Sulak alan çok daha büyük bir alan kaplamakta iken $\left(11.70 \mathrm{~km}^{2}\right)$ tarım alanı kazanmak, su baskınlarını önlemek, tarım sahalarını sulamak ve elektrik enerjisi elde etmek amaciyla üç yandan seddelerle kuşatılmış ve bu durum sulak alanın beslenim şartlarının ve sınırlarının değişmesine sebep olmaktadır. Ayrıca, bölgenin su rejimine etki edip suların kimyasal ve fiziksel özelliklerinde farklılaşmaya yol açmaktadır (Polat vd., 2011).

Göl alanının büyük çoğunluğu hasırotu, kamış ve nilüferle kaplıdır ve gölün üzerinde irili ufaklı çok sayıda yüzen ada bulunmaktadır. Yapılan çalışmalarda, Karakuyu Gölü'nün korunması gereken önemli sulak alanlarımızdan biri olduğu ve göl sularının içme ve kullanma suyu temini açısından büyük önem taşıdığı belirtilmektedir (Polat vd., 2011; Bulut vd., 2016; Özdemir ve Gür, 2016). Karakuyu Gölü'nde yaşanan çevre sorunlarının başında su yönetimi gelmekte ve gölün ortasından geçen demiryolu, saz kesimi, kontrolsüz torf alımı, kontrolsüz avcıllk gibi beșeri müdahaleyle birlikte, su ve toprak kirliliği şeklinde çevre sorunları oluştuğu tespit edilmiștir (Bulut vd., 2016).

Mevcut durumda, Karakuyu Gölü Sulak Alanı'nın hidrojeolojik ve hidrojeokimyasal incelemesinin yapılarak bölgedeki hidrojeolojik yapının ve su kalitesinin ortaya konulması doğal bir kaynak olan Karakuyu Gölü Sulak Alanı'nın korunması ve sürdürülebilir yönetimi açısından büyük önem taşımaktadır.

\section{Materyal ve Yöntem}

Karakuyu Gölü Sulak Alanı ve yakın çevresi Afyon ilinin Dinar ilçesi sınırları içerisinde yaklaşı 361 $\mathrm{km}^{2}$ lik bir alanı kapsamaktadır (Şekil 1). $38^{\circ} 02^{\prime} \mathrm{K}$ enlemi - $30^{\circ} 14^{\prime}$ D boylamında ve Dinar yol ayrımının $10 \mathrm{~km}$ güneyinde bulunmakta olan Karakuyu Gölü sulak alanı 1/100 000 ölçekli Afyon L24 paftası içerisinde yer almaktadır. 


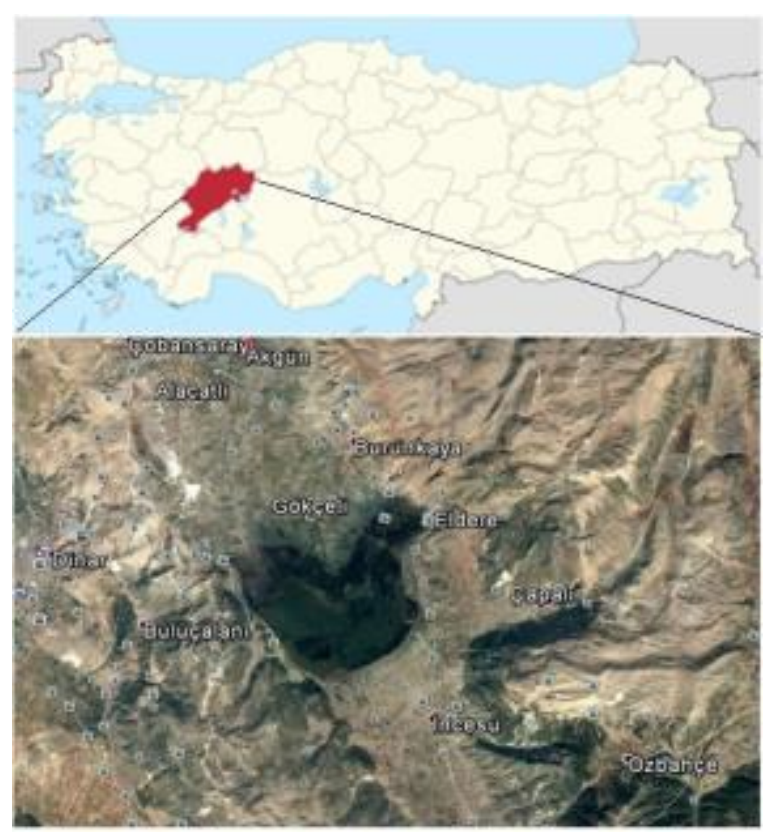

Şekil 1. Çalışma alanının yerbulduru haritası

Karakuyu Gölü sulak alanı, Çapalı, Eldere, Gökçeli, İncesu Gölü olarak da bilinmekte olup hidrografik yönden Büyük Menderes Nehir havzasının yukarısında yeralmaktadır. Sulak alanın doğusunda Karakuş Dağı $(2000 \mathrm{~m})$ ve Barladağı $(1780 \mathrm{~m})$, batısında Akdağ (2445 m) ve Samsun Dağı, kuzeyinde ise Kumalar Dağı $(2440 \mathrm{~m})$ bulunmaktadır. Akgün, Burunkaya, İncesu, Eldere, Gökçeli, Karakuyu, Çapalı sulak alanın yakın çevresinde bulunan yerleşim yerleridir.

Karakuyu Gölü sulak alanı ve yakın çevresinin hidrojeolojik ve hidrojeokimyasal incelemelerini kapsayan bu çalışma ile bölgenin jeolojik ve hidrolojik özelliklerinin yanısıra yeraltısuyu seviyesi ve dinamiği, suların hidrojeokimyasal özellikleri, kullanım alanları ve su kalitesi belirlenmiştir. Çalışma alanının stratigrafik ve yapısal özelliklerinin belirlenmesi için öncelikle ayrıntılı literatür incelemesi yapılarak bölgede daha önce yapılmıș çalışmalar incelenmiştir. Elde edilen bilgiler arazi gözlemleri ile birleştirilerek çalışma alanının 1/50.000 ölçekli jeoloji haritası oluşturulmuștur. Jeolojik çalışmalarla belirlenen litolojik birimlerin hidrojeolojik özellikleri dikkate alınarak çalışma alanının hidrojeoloji haritası hazırlanmıștır. Çalıșma alanının yeraltısuyu seviye haritası bölgede yeralan sondaj kuyularında ölçülen (Kasım-2015) statik seviye değerleri kullanılarak hazırlanmış ve yeraltısuyu akım yönü ile hidrolik eğim değerleri belirlenmiștir.

Karakuyu Gölü sulak alanın hidrojeokimyasal yapısı, kullanım özellikleri ve su kalitesini belirleyebilmek için çalışma alanının farklı lokasyonlarından Kasım2015 döneminde kaynak suları ve göl sularından 15 adet su örneği alınarak katyon ve ağır metal analizleri yaptırılmıştır. Sıcaklık, elektriksel iletkenlik (EC), toplam çözünmüş katı madde (TDS) ve hidrojen iyonu konsantrasyonu $(\mathrm{pH})$ değerleri ise Elmetron CX-401 ve YSI Professional Plus marka çok parametreli portatif su kalitesi ölçüm cihazı kullanılarak yerinde ölçümler ile belirlenmiştir. Su örneklerinin katyon ve ağır metal analizleri ACME laboratuarlarında Grup 2C kapsamında, ICP-MS (Inductively Coupled Plasma-Mass Spectrometer) analiz tekniği kullanılarak belirlenmiștir. Azot türevleri, sülfat, klorür analizleri WTW photoLab Spectral-12 Spektrofotometre cihazı kullanılarak fotometrik yöntem ile; $\mathrm{CO}_{3}$ ve $\mathrm{HCO}_{3}$ analizleri ise Merck-Aquamerck test kitleri kullanılarak titrimetrik tayin ile SDÜ Jeotermal Enerji, Yeraltısuyu ve Mineral Kaynakları Araştırma ve Uygulama Merkezi laboratuarında yapılmıștır. Kimyasal analiz sonuçları çeşitli diyagram ve haritalar üzerinden incelenerek ve ilgili yönetmelikler ile belirlenen sınır değerler ile karşılaştırılarak suların hidrojeokimyasal özellikleri, içme ve sulama suyu olarak kullanım özellikleri ve kalite durumu ortaya konulmuştur.

\section{Araştırma Bulguları}

\subsection{Genel Jeoloji ve Hidrojeoloji}

Çalışma alanındaki jeolojik birimlerin litolojik özellikleri ve stratigrafik ilişkisi incelendiğinde bölgede farklı yaş ve litolojiye sahip çok sayıda jeolojik birim yüzeylenmektedir. Çalışma alanı içerisinde yer alan formasyonlar yaşlıdan gence doğru; Dutdere kireçtaşı (TRjd), Gökhacıdağ formasyonu (Kg), Büyükkırtepe formasyonu (Tpeb), Dereköy formasyonu (Ted), Yavuz formasyonu (Tey), Akçaköy formasyonu (Toak), Acıgöl grubu (Toa), Çameli formasyonu (Tplç) ve Kireçtaşı üyesi (Tplçk), Kepeztepe formasyonu (PlQk), Eski akarsu taraça dolgusu (Qt), yamaç molozu (Qym) ve alüvyon (Qal) olup çalışma alanının 1/50 000 ölçekli genel jeoloji haritası Şekil 2'de verilmiştir. Bölgede temel birimi oluşturan ve megalodonlu kristalize kireçtaşlarından meydana gelen Dutdere kireçtaşı, Ersoy (1989) tarafından adlandırılmıştır. Birim orta-kalın tabakalı, masif, aşınma yüzey rengi gri, kırılma yüzeyi beyaz, kirli beyaz, krem, bej, gri, megalodonlu ya da algli rekristalize kireçtaşlarından oluşmaktadır. Birimin üst düzeyinde orta-kalın tabakalı, gri, krem renkli kireçtaşları bulunur. Bunların üzerinde de pembekırmızı renkli, yerel olarak çörtlü, ammonitli yumrulu kireçtaşları yeralmaktadır (Şenel, 1997). Sı̆̆ bir karbonat şelf ortamında çökeldiği belirlenen formasyonun toplam kalınlığı 700 metreye ulaşmaktadır. Birimin yaşı içerdiği fosil bileșenlerine göre Orta Triyas olarak belirlenmiştir (Şenel vd., 1989) .Çalışma alanının doğusunda oldukça geniş bir yayılım sunan Gökhacıdağ formasyonu platform karbonatlar ve pelajik faunalı çörtlü kireçtaşlarından oluşmuştur ve birimin adlandırması Öztürk ve Öztürk (1989) tarafından yapılmıştır. Birimin alt düzeyleri 
koyu gri, mavi, bej renkli, orta-kalın tabakalanmalı, dolomit mercekleri içeren biyomikritlerden oluşmaktadır. Kretase yaşlı birim üste doğru gidildikçe bej, gri, siyah renkli, kalın tabakalanmal, masif, dolomit mercekli, oolitli, organizma kırıntılı, sıkı tutturulmuş biyomikrit ve biyolitlerle devam etmektedir (Balcl, 2011). 1200 metreden fazla kalınlığa sahip olan formasyonun üstte Büyükkırtepe formasyonu tarafindan üzerlenmektedir. Resifal ve türbiditik seviyeli pelajik faunalı kireçtaşlarından oluşan Büyükkırtepe formasyonu Öztürk ve Öztürk (1989) tarafından adlandırılmıştır. Formasyon beyaz, krem renkli, orta-kalın tabakalanmalı, belirgin eklemli, nummulit ve algli kireçtaşları ile başlamaktadır ve iri kalsit damarlı kireçtaşlarına geçmektedir. Yaklaşık $50 \mathrm{~m}$ ile $175 \mathrm{~m}$ civarında kalınlığa sahip olan birim stratigrafik olarak Orta Eosen yașlı Dereköy formasyonu ile yanal ve düșey yönde geçişlidir. Dereköy formasyonu türbiditik kumtaşı ile killi kireçtaşı, şeyl, marn ve kiltaşı ardalanmasından oluşmaktadır. Formasyon altta bordo renkli, ince tabakalı, yapraklanmalı, çört bant ve yumrulu, Globigerina' lı kireçtaşları ile başlamaktadır. Üstüne gelen şeyl, kiltaşı, çamurtaşı, marn ardalanması bordo, sarımsı, alacalı renkli ve ince tabakalıdır. Formasyonun egemen kaya türü sarı, boz, alacalı renkli, orta-kalın tabakalanmalı, kaba kum boyutunda, kısmen derecelenmeli, çok tür bileşenli, taneleri köşeli kumtaşlarıdır.

Yaklaşık $1000 \mathrm{~m}$. kalınlığa sahip olan birim üzerine Yavuz formasyonu tektonik olarak yerleşirken aynı zamanda birim Alt-Orta Oligosen yaşlı Akçaköy formasyonu tarafindan uyumsuzlukla üzerlenmektedir. Birim çalıșma alanı güneyinde İncesu, Çapalı mevkiinde dar alanlarda gözlenmektedir. Kireçtaşı ara seviyeli kumtaşı ve kiltaşlarından oluşan Yavuz formasyonu çalışma alanının batısında dar uzun bir hat halinde yüzeylenmektedir. Birim, ince-orta-kalın tabakalı, bej, krem, gri, kirli sarı, yeşil, kumlu- killi kireçtaşı, kalsitürbidit ve mikritik kireçtaşı ara seviyeli kumtaşı, kiltaşı ve silttaşlarından oluşmaktadır. Birimde üste doğru kireçtaşı oranı azalır. Birim içerisindeki kireçtaşı seviyeleri aşırı deformasyon nedeniyle makaslanmış ve blok görünümü kazanmıştır. Türbiditik özellikte olan formasyonda seyrek mikrokonglomera düzeyleri görülmektedir (Şenel, 1997).Birimin yaşı fosil içeriğine göre ÜstOrta Eosen olarak verilmiștir (Șenel vd., 1989).

Akçaköy formasyonu altta sarımsı, bej, gri renkli, kötü tabakalanmalı, çok tür bileşenli çakıltaşları ile başlar. Bileșenler yarı yuvarlak, yuvarlak olup kumblok boyutlarındadır. Çakıltaşı kötü boylanmalı ve kötü derecelenmelidir. Bileşenleri, çoğunlukla Triyas, Jura, Kretase, Eosen ve Permiyen yaşlı kireçtaşları ile çört, diyabaz, serpantin, andezitik ve bazaltik tüfler, radyolarit, şist parçaları ve kumtaşıdır. Alt-orta Oligosen yaşlı birimin kalınlığı yaklaşı 300-1000 m arasında olup birim Oligosen yaşlı Acıgöl grubuna ait çökeller tarafından örtülmektedir.Acıgöl Grubu kalın konglomeralardan meydana gelmektedir. Açık gri, açık bej renklerde, kalın tabakalı, karbonat çimentolu çakıltaşlarından oluşmuş olan birim içerisindeki taneler Permiyen ve Eosen 'e ait taneler olarak tanımlanmıştır. Birim içerisinde yer yer kumtaşı ve çamurtaşı aratabakaları da izlenmektedir (Balcı, 2011). Acıgöl grubualtta Akçaköy formasyonu ile dokanak sunarken üstte Çameli formasyonuna ait birimler tarafindan uyumsuz olarak üzerlenmektedir.

Çameli formasyonu, ince-orta-kalın tabakalı, beyaz, kirli beyaz, kirli sarı, açık gri, yeşil vb. renklerde kiltaşı, kumtaşı, marn, konglomera ve kumtaşlarından oluşmaktadır. Birim içinde tüf ve tüfit düzeyleri görülebilir (Balcı 2011). Çameli formasyonunun üst kesimlerinde bulunan kireçtaşı üyesi ince- orta- kalın tabakalıdır ve kirli sarı, bej, krem, açık kahve renkli kireçtaşı ve travertenlerden oluşmaktadır.Kumtaşı ve mercekli çakıltaşlarından meydana gelen Kepeztepe formasyonu çalışma alanının güneyinde çok dar alanda görülmektedir.Çakıltaşı çok tür bileşenli olup bileșenleri kum ile blok boyutları arasında değişmektedir. Kireçtaşı, ofiyolit, volkanit, şist, radyolarit, kumtaşı gibi kayaçlardan oluşmakta olan birim kötü boylanmalı, kötü derecelenmeli, gevşek tutturulmuş, kum veya karbonat çimentoludur. Birimin kalınlığı 50 ile 75 metre civarında olup içerisinde herhangi bir fosil içermeyen formasyonun yaşı stratigrafik ilişkilerine göre Pliyo-Kuvaterner olarak verilmiştir (Balcı, 2011).

Çalışma alanında bulunan Kuvaterner birimlerden Eski akarsu taraça dolgusu, gevşek tutturulmuş çakıl, blok ve çok az oranda kum ve çamur birikintilerinden, yamaç molozu çakıl ve blok birikintilerinden oluşmaktadır. Bölgede geniş bir yayılım sunan alüvyon ise gevșek tutturulmuş kil, silt, kum, çakıl ve bloktan oluşan güncel çökelleri oluşturmakta ve genel olarak topografyanın düz olduğu ovada ve dere yataklarında yüzeylenmektedir. 


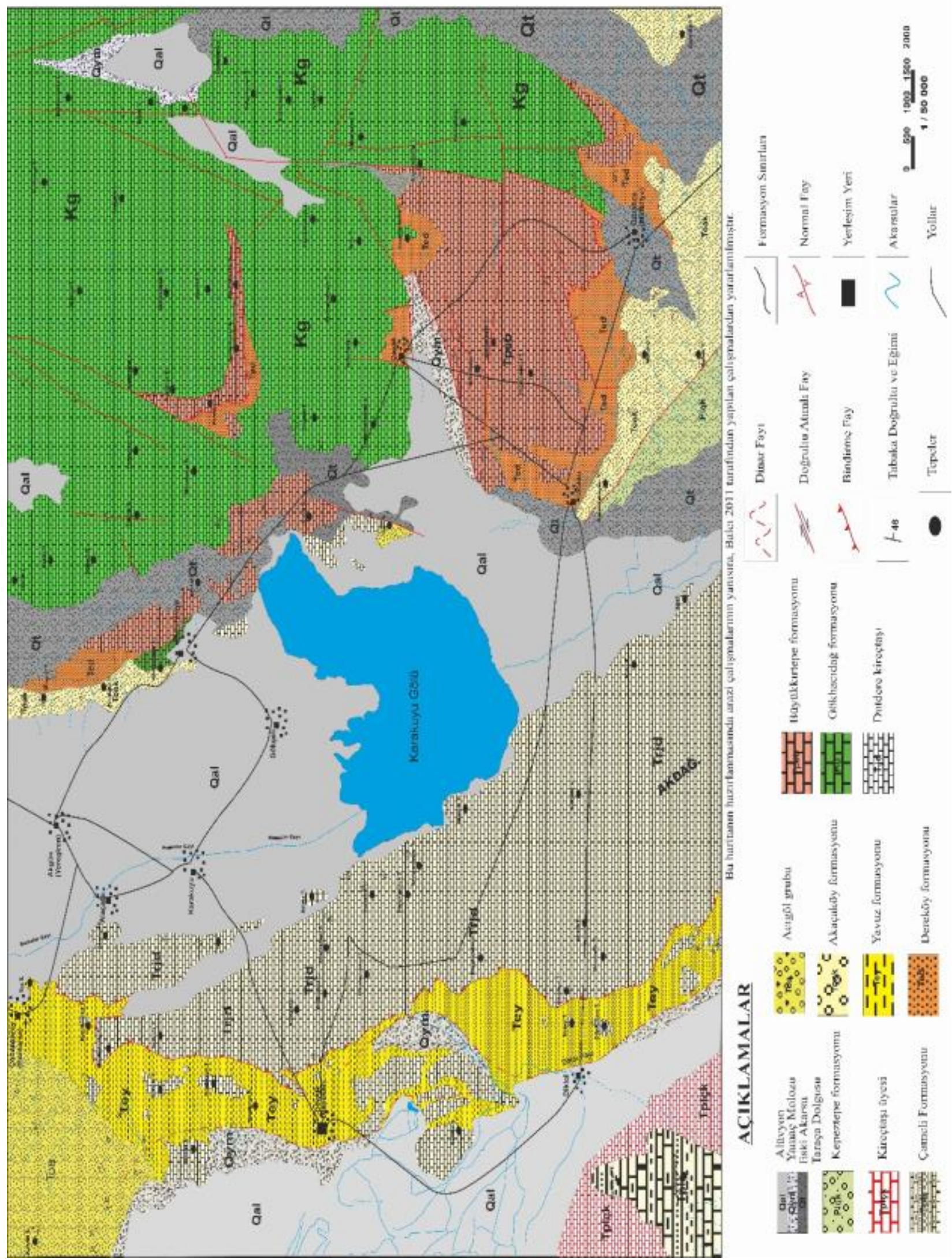

Şekil 2. Çalışma alanının genel jeoloji haritası 
Sulak alanın beslenmesini sağlayan başlıca yüzey suları Kirazlı Dere, Çakalboğazı Dere, Kumalar Çayı, Bucak Dere, Güdül Dere ve Çay Deresidir. Ancak bu akarsuların bazıları gölün kuzeyindeki drenaj kanallarına bağlanmıș olup akarsu yatakları yaz ve sonbahar mevsimlerinde kurumaktadır. Gölü ve sulak alanı besleyen en önemli kaynak boşalımı ise gölün güneydoğusundaki karstik kireçtaşlarından boşalan Eldere (Kocapınar, Pınarbaşı, Ulupınar) kaynağı'dır. Ayrıca, Eldere kaynağının kuzey-kuzeybatısında grup kaynaklar olarak aynı karstik kireçtaşlarından boşalan Burunkaya kaynakları bulunmaktadır. Çalışma alanı içerisinde yer alan litoloji birimler hidrojeolojik özellikleri dikkate alınarak Akifüj Ortam (Akj);Akitard Ortam (Akt);Erimeli Çatlaklı Kaya Ortam Akiferi (Akf-2) ve Taneli Ortam Akiferi (Akf-1) olmak üzere dört ayrı grupta incelenmiştir(Şekil 3). Çalışma alanında doğusunda dar alanlarda yüzeyleyen Dereköy formasyonu içerdiği kumtaşışeyl-marn-kiltaşı seviyelerinden dolayı Akifüj Ortam (Akj) olarak tanımlanmıştır. Yavuz formasyonu, Akçaköy formasyonu, Acıgöl grubu, Kepeztepe formasyonu ve Çameli formasyonu kumtaşıçamurtaşı-marn-konglomera ve yer yer ofiyolit şist gibi benzer litolojik özelliklere sahip olmalarından dolayı yarı geçirimli birim olan Akitard Ortam (Akt) olarak sınıflandırılmıştır.

Çalışma alanındaki kireçtaşı ve dolomitlerden oluşan Gökhacıdağ formasyonu, Büyükkırtepe formasyonu, Dutdere kireçtaşı ve Çameli formasyonu kireçtaşı üyesi karstik yapılarından dolayı Erimeli Çatlaklı Kaya Ortam Akiferini temsil etmekte olup Akifer-2 olarak tanımlanmıştır. Burunkaya mevkiinde açılmış olan sondaj kuyularından 25119 nolu kuyuda Dutdere karstik kireçtaşlarına girilmiş ve geçilen karstik boşluk oranlarına bağlı olarak $39.1 \mathrm{l} / \mathrm{sn}$ verim elde edilmiștir. Aynı bölgede açılmış olan 25118 nolu kuyuda kireçtaşı birimi kesilmemiş ve bu nedenle elde edilen verim $3.32 \mathrm{l} / \mathrm{sn}^{\prime}$ de kalmıștır. Havza güneyinde açılan DSİ su sondaj kuyularından, Çapalı 26816 ve 24821 nolu kuyularda Gökhacıdağ formasyonu kireçtaşları kesilmekte ve yeraltısuyu bu formasyondan alınmaktadır. Bu kuyuların debileri havzanın kuzeyine göre daha yüksek olup ortalama 70-80 l/sn verim ölçülmüştür.

Ovanın büyük bir kısmını olușturan alüvyon ile yamaç molozu ve eski akarsu taraça dolgusu gözenekli yapıları, yayılımları ve verimleri dikkate alınarak Taneli Ortam Akiferi (Akifer-1) olarak sınıflandırılmıştır. Havzada açılan sondaj kuyu loglarına göre, genç alüvyon örtünün kalınlı̆̆ı, en kalın olduğu alanlarda, $20 \mathrm{~m}$ ile $25 \mathrm{~m}$ arasında değişmektedir. Alüvyon havzada yaygın olarak çökelmiş Kepeztepe formasyonuna ait göl çökelleri üzerine yerleșmiștir. Alüvyon örtüdeki kumlu, çakıllı geçirgen birimlerin, kuzeye doğru dere yatakları boyunca kalınlaştığı görülmektedir.

Çalışma alanında bulunan yeraltısuyu kuyuları genel olarak ovada alüvyon birim üzerinde açılmıştır. Bu birimde yeraltısuyu seviyesini ve yeraltısuyu akım yönünü belirleyebilmek amacıyla mevcut sondaj kuyularında yeraltısuyu seviye ölçümleri gerçekleștirilmiştir. Bölgede FurgoSial (2014) tarafından yapılmış olan yeraltısuyu seviye ölçümleri de dikkate alınarak bölgenin yeraltısuyu seviye haritası hazırlanmıștır (Şekil 3). Alüvyon ortamda bulunan kuyulardan alınan ölçüm sonuçlarına göre bölgedeki yeraltısuyu seviyesi 0 ile $15,15 \mathrm{~m}$ arasındadır. Yeraltısuyu seviye değerlerine göre hazırlanan yeraltısuyu seviye eğrileri incelendiğinde, yeraltısuyu yüzeyinin morfolojisinin düzgün olduğu görülmektedir. Seviye eğrileri birbirine paralel ve gidişleri düzgündür. Bölgede yeraltısuyu akımının gölün kuzeyinde güneye, gölün güneyinde ise kuzeykuzeybatıya olmak üzere Karakuyu Gölü'ne doğru olduğu görülmektedir. Bölgede hesaplanan hidrolik eğim değerleri ise 0.01 ile 0.005 arasında değişmektedir.

Çalışma alanında bulunan akiferlerin hidroloji parametrelerini belirleyebilmek için bölgede yeralan DSİ 18. Bölge Müdürlüğü tarafindan açılmış olan sondaj kuyularından 4 tanesinin verileri kullanılmıştır. Bu kuyularda açıldıkları tarih itibariyle yapılan pompaj deneylerinden elde edilen zamandüșüm değerleri ile akiferlerin permeabilite katsayısı (K), transmisibilite katsayısı (T) ve depolama katsayısı (S) değerleri Cooper-Jacop Time Drawndown yöntemi kullanılarak hesaplanmıștır. Bu yöntem, gözenekli akiferde, izotrop şartlarda, sabit debili pompaj için akiferin sonsuza kadar uzandığını ve kuyunun tüm akifer kalınlığını kestiğini kabul etmektedir. Çalışma alanında alüvyon ve kireçtaşı seviyelerinden yeraltısuyu alınmaktadır.

Yapılan hesaplamalar sonucunda taneli ortam akiferi olarak tanımlanan alüvyonda açılmış olan kuyularda permeabilite kaysayısı $2.53 \times 10^{-6} \mathrm{~m} / \mathrm{s}$ ile $7.21 \times 10^{-6}$ $\mathrm{m} / \mathrm{s}$, transmisibilite katsayıs $1,01 \times 10^{-4} \mathrm{~m}^{2} / \mathrm{s}$ ile $3,82 \times 10^{-4} \mathrm{~m}^{2} / \mathrm{s}$, depolama katsayısı ise \% 14 ile 23 arasında değişmektedir. Alüvyon ve kireçtaşının birlikte kesildiği 25119 nolu kuyu verilerine göre kuyunun $32 \mathrm{l} / \mathrm{sn}$ debiye sahip olduğu ve permeabilite katsayısının (K) $9,59 \times 10^{-6} \mathrm{~m} / \mathrm{s}$, transmisibilite

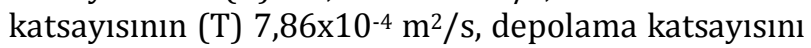
ise $\% 35$ olduğu belirlenmiștir. 


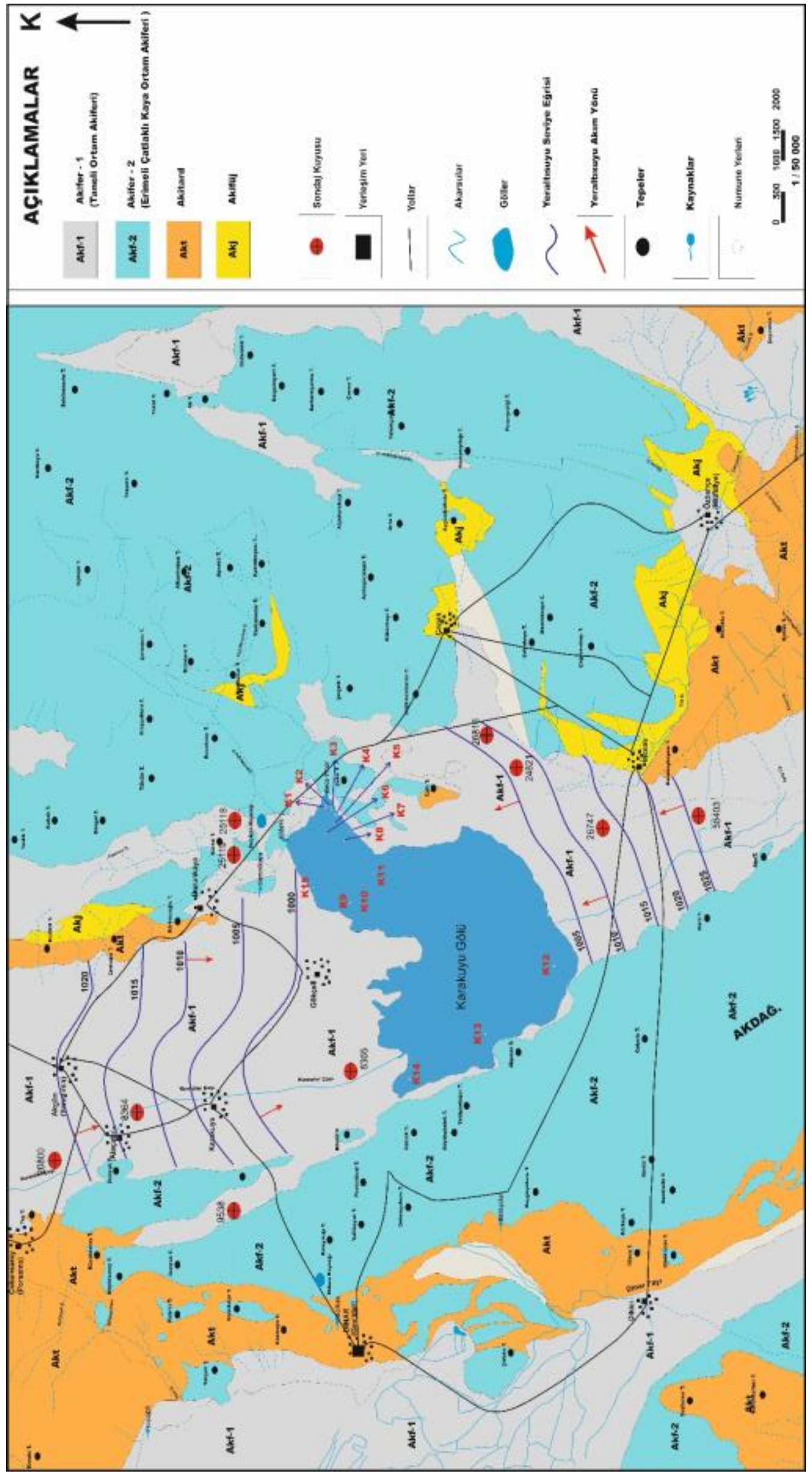

Şekil 3. Çalışma alanının hidrojeoloji haritası 


\subsection{Hidrojeokimya}

Karakuyu Gölü sulak alanın hidrojeokimyasal yapısı, kullanım özellikleri ve su kalitesini belirleyebilmek için çalışma alanının farklı lokasyonlarından Kasım2015 döneminde 15 adet su örneği alınmıştır. Su örneklerinin kimyasal analiz sonuçları Tablo 2 ve 3'de verilmiştir.

Suların iyon özelliklerinin tanımlanmasında, genel kimyasal özellikler değerlendirilmiş ve Schoeller (1955), Piper (1944), Gibbs (1970) ve Chadha (1999) diyagramları kullanılarak yorumlamaları yapılmıștır. Suların kullanılabilirlik durumunun değerlendirilmesinde ise ulusal ve uluslararası standartların yanısıra H. Scholler İçilebilirlik, ABD tuzluluk ve Wilcox (1955) diyagramları kullanılmıștır. Ayrıca alınan örneklerin kalite durumu ağır metal ve azot türevleri bakımından değerlendirilmiștir.

Çalışma alanından alınan su örneklerin $\mathrm{pH}$ değerleri 7.30-7.8 arasında olup suların tamamı bazik karakterli sular sınıfındadır. Alınan örneklerin toplam sertlik değerleri 5,91-9,77 arasında değişmektedir. Bu değerlere göre çalışma alanındaki sular çok yumuşak ve yumuşak sular sınıfında yer almaktadır (Tablo 4).

Tablo 4. Suların sertliklerine göre sınıflandırılması (Şahinci 1991)

\begin{tabular}{|c|c|}
\hline Fransız Sertliği(Fro) & Su Sınıfı \\
\hline $0.0-7.2$ & Çok yumuşak \\
\hline $7.2-14.5$ & Yumuşak \\
\hline $14.5-21.5$ & Az sert \\
\hline 21.32 .5 & Oldukça sert \\
\hline $32.5-54.0$ & Sert \\
\hline$>54.0$ & Çok sert \\
\hline
\end{tabular}

Suların elektriksel iletkenliği iyon bolluğuna ve varlığına, toplam derişimine ve sıcaklığa bağlı olarak değişmektedir ve iletkenlik, iyon konsantrasyonu ile doğru orantılıdır (Şahinci, 1991). Çalışma alanındaki su numunelerinin özgül elektriksel iletkenlik (EC) değerleri 347-521 $\mu \mathrm{mho} / \mathrm{cm}$ arasında değişmektedir. Çalışma alanındaki suların analiz sonuçları kullanılarak hesaplanan SAR değerleri genel olarak 0.09-0.13 arasında; \% $\mathrm{Na}$ değerleri ise 2.74-4.19 arasında değişmektedir. Tablo 5'de verilen Schoeller (1955)'in yapmış olduğu sınıflamaya göre alınan su numunelerinin tamamı, karbonat+bikarbonat, klorür ve sülfat derişimi bakımından "olağan karbonatlı", "olağan klorürlü" ve "olağan sülfatlı sular" sınıfında yeralmaktadır. 
Tablo 2. Su örneklerinin kimyasal analiz sonuçları

\begin{tabular}{|c|c|c|c|c|c|c|c|c|c|c|c|c|c|c|c|c|c|c|c|c|}
\hline $\begin{array}{r}\text { Num } \\
\text { no }\end{array}$ & $\begin{array}{c}\text { Numune } \\
\text { Yeri }\end{array}$ & $\begin{array}{c}\mathrm{Na}^{+} \\
\mathrm{mek} / \mathrm{l}\end{array}$ & $\begin{array}{c}\mathrm{K}^{+} \\
\text {mek/l }\end{array}$ & $\begin{array}{c}\mathrm{Ca}^{++} \\
\mathrm{mek} / \mathrm{l}\end{array}$ & $\begin{array}{c}\mathrm{Mg}^{++} \\
\mathrm{mek} / \mathrm{l}\end{array}$ & $\begin{array}{c}\mathrm{Cl}^{-} \\
\mathrm{mek} / \mathrm{l}\end{array}$ & $\begin{array}{c}\mathrm{SO}_{4}^{-2} \\
\mathrm{mek} / \mathrm{l}\end{array}$ & $\begin{array}{c}\mathrm{HCO}_{3}^{-} \\
\mathrm{mek} / \mathrm{l}\end{array}$ & Sic. $\left(\mathbf{C}^{0}\right)$ & $\begin{array}{c}\text { Sertlik } \\
\left(\mathbf{F r}^{0}\right)\end{array}$ & $\begin{array}{c}\text { EC } \\
\mu \mathrm{mho} / \mathrm{c} \\
\mathrm{m}\end{array}$ & TDS & pH & $\% \mathrm{Na}$ & SAR & PI & KI & MT & RSC & Su Sınıfi \\
\hline K1 & \begin{tabular}{|c|} 
Eldere \\
Kaynağ
\end{tabular} & 0.16 & 0.06 & 2.98 & 0.98 & 0.06 & 0.06 & 3.90 & 13.30 & 5.96 & 349.00 & 223.00 & 7.63 & 3.82 & 0.11 & 51.79 & 0.040 & 24.74 & -0.06 & $\mathrm{Ca}-\mathrm{HCO}_{3}$ \\
\hline $\mathrm{K} 2$ & $\begin{array}{c}\text { Eldere } \\
\text { Kaynağı } \\
\end{array}$ & 0.14 & 0.02 & 2.95 & 1.00 & 0.06 & 0.06 & 3.60 & 14.20 & 5.91 & 384.00 & 246.00 & 7.75 & 3.40 & 0.09 & 49.80 & 0.035 & 25.34 & -0.351 & Ca-Mg-HCO \\
\hline K3 & \begin{tabular}{|c|} 
Karakuyuu \\
Gölü
\end{tabular} & 0.15 & 0.02 & 3.04 & 1.01 & 0.06 & 0.06 & 3.60 & 13.50 & 6.09 & 376.00 & 241.00 & 7.70 & 3.55 & 0.10 & 48.73 & 0.037 & 24.93 & -0.45 & $\mathrm{Ca}-\mathrm{Mg}-\mathrm{HCO}_{3}$ \\
\hline $\mathrm{K} 4$ & $\begin{array}{c}\text { Karakuyu } \\
\text { Gölüu }\end{array}$ & 0.14 & 0.03 & 2.98 & 1.01 & 0.07 & 0.06 & 3.50 & 15.00 & 5.96 & 363.00 & 232.00 & 7.66 & 3.36 & 0.09 & 48.66 & 0.035 & 25.31 & -0.49 & $\mathrm{Ca}-\mathrm{Mg}-\mathrm{HCO}_{3}$ \\
\hline K5 & $\begin{array}{c}\text { Karakuyu } \\
\text { Gölü }\end{array}$ & 0.14 & 0.04 & 3.02 & 1.01 & 0.06 & 0.06 & 4.10 & 14.30 & 6.05 & 359.00 & 230.00 & 7.75 & 3.32 & 0.09 & 51.89 & 0.034 & 25.06 & 0.07 & $\mathrm{Ca}-\mathrm{Mg}-\mathrm{HCO}_{3}$ \\
\hline K6 & $\begin{array}{l}\text { Karakuyu } \\
\text { Gölü }\end{array}$ & 0.15 & 0.03 & 3.00 & 1.00 & 0.06 & 0.06 & 3.90 & 14.40 & 6.00 & 347.00 & 222.00 & 7.55 & 3.58 & 0.10 & 51.14 & 0.037 & 25.05 & -0.10 & Ca-Mg- $\mathrm{HCO}_{3}$ \\
\hline K7 & \begin{tabular}{|c|} 
Karakuyu \\
Gölü \\
\end{tabular} & 0.15 & 0.03 & 3.01 & 1.02 & 0.06 & 0.06 & 4.00 & 14.00 & 6.03 & 377.00 & 241.00 & 7.75 & 3.56 & 0.10 & 51.43 & 0.037 & 25.31 & -0.03 & Ca-Mg-HCO \\
\hline K8 & $\begin{array}{c}\text { Karakuyu } \\
\text { Gölü } \\
\end{array}$ & 0.14 & 0.03 & 3.00 & 1.03 & 0.06 & 0.06 & 3.90 & 13.50 & 6.00 & 368.00 & 235.00 & 7.75 & 3.33 & 0.09 & 50.67 & 0.034 & 25.54 & -0.132 & Ca-Mg-HCO \\
\hline K9 & $\begin{array}{c}\text { Karakuyu } \\
\text { Gölü }\end{array}$ & 0.17 & 0.05 & 3.18 & 1.06 & 0.08 & 0.06 & 4.30 & 11.90 & 6.37 & 360.00 & 230.00 & 7.76 & 3.81 & 0.11 & 50.86 & 0.040 & 25.00 & 0.06 & Ca-Mg-HCO \\
\hline K10 & $\begin{array}{c}\text { Karakuyu } \\
\text { Gölü }\end{array}$ & 0.15 & 0.03 & 3.03 & 1.01 & 0.09 & 0.06 & 4.00 & 11.80 & 6.06 & 353.00 & 226.00 & 7.84 & 3.55 & 0.10 & 51.31 & 0.037 & 25.00 & -0.04 & Ca-Mg- $-\mathrm{HCO}_{3}$ \\
\hline K11 & \begin{tabular}{|c|} 
Karakuyu \\
Gölü \\
\end{tabular} & 0.19 & 0.02 & 3.80 & 1.41 & 0.05 & 0.04 & 5.40 & 7.30 & 7.61 & 438.00 & 280.00 & 7.56 & 3.50 & 0.11 & 46.53 & 0.036 & 27.06 & 0.19 & Ca-Mg-HCO \\
\hline K12 & \begin{tabular}{|c|} 
Karakuyu \\
Gölü \\
\end{tabular} & 0.18 & 0.02 & 4.62 & 1.73 & 0.05 & 0.04 & 6.30 & 9.00 & 9.24 & 521.00 & 333.00 & 7.30 & 2.74 & 0.10 & 41.17 & 0.028 & 27.24 & -0.05 & Ca-Mg-HCO \\
\hline K13 & \begin{tabular}{|c|} 
Karakuyu \\
Gölü \\
\end{tabular} & 0.20 & 0.03 & 4.88 & 1.52 & 0.05 & 0.02 & 5.80 & 13.70 & 9.77 & 504.00 & 322.00 & 7.30 & 3.01 & 0.11 & 39.51 & 0.031 & 23.75 & $\begin{array}{l}-0.60 \\
\end{array}$ & Ca-Mg-HCO \\
\hline K14 & $\begin{array}{l}\text { Karakuyu } \\
\text { Gölü }\end{array}$ & 0.15 & 0.02 & 3.85 & 1.21 & 0.03 & 0.05 & 4.90 & 10.80 & 7.70 & 424.00 & 271.00 & 7.75 & 2.86 & 0.09 & 45.35 & 0.029 & 23.91 & -0.16 & Ca-Mg- $\mathrm{HCO}_{3}$ \\
\hline K15 & $\begin{array}{c}\text { Karakuyu } \\
\text { Gölü }\end{array}$ & 0.22 & 0.04 & 3.69 & 1.29 & 0.06 & 0.04 & 5.00 & 9.30 & 7.39 & 433.00 & 277.00 & 7.74 & 4.19 & 0.13 & 47.23 & 0.044 & 25.90 & 0.02 & $\mathrm{Ca}-\mathrm{Mg}-\mathrm{HCO}_{3}$ \\
\hline
\end{tabular}


Tablo 3. Su örneklerinin ağır metal ve azot türevleri analiz sonuçları

\begin{tabular}{|c|c|c|c|c|c|c|c|c|c|c|c|c|c|c|c|c|c|c|}
\hline \multirow{2}{*}{ Örnek no } & \multirow{2}{*}{ Koordinat } & \multirow{2}{*}{$\begin{array}{c}\text { Numune } \\
\text { Yeri } \\
\end{array}$} & $\mathrm{Al}$ & Mn & $\mathrm{Cu}$ & $\mathrm{Zn}$ & $\mathbf{P b}$ & $\mathrm{Hg}$ & Cd & Se & $S$ & As & $\mathrm{Fe}$ & $\mathrm{Cr}$ & $\mathrm{Ni}$ & $\mathrm{NO}_{2}$ & $\mathrm{NO}_{3}$ & $\mathrm{NH}_{4}$ \\
\hline & & & $\mu \mathrm{g} / \mathrm{l}$ & $\mu \mathrm{g} / \mathrm{l}$ & $\mu \mathrm{g} / \mathrm{l}$ & $\mu \mathrm{g} / \mathrm{l}$ & $\mu \mathrm{g} / \mathrm{l}$ & $\mu \mathrm{g} / \mathrm{l}$ & $\mu \mathrm{g} / \mathrm{l}$ & $\mu \mathrm{g} / \mathrm{l}$ & $\mathrm{mg} / \mathrm{l}$ & $\mu \mathrm{g} / \mathrm{l}$ & $\mu \mathrm{g} / \mathrm{l}$ & $\mu \mathrm{g} / \mathrm{l}$ & $\mu \mathrm{g} / \mathrm{l}$ & $\mathrm{mg} / \mathrm{l}$ & $\mathrm{mg} / \mathrm{l}$ & $\mathrm{mg} / \mathrm{l}$ \\
\hline \multirow[t]{2}{*}{ K1 } & $3804^{\prime} 29.3^{\prime \prime} \mathrm{K}$ & Eldere & 9.00 & 0.37 & 1.00 & 9.60 & 0.60 & $<0.1$ & $<0.05$ & $<0.5$ & 2.00 & 3.40 & $<10$ & 1.80 & 0.80 & $<0.01$ & 7.33 & $<0.06$ \\
\hline & $3016^{\prime} 31.9^{\prime \prime} \mathrm{D}$ & Kaynağı & & & & & & & & & & & & & & & & \\
\hline \multirow[t]{2}{*}{ K2 } & $3804^{\prime} 28.7^{\prime \prime} \mathrm{K}$ & Eldere & 2.00 & $<0.05$ & 0.40 & 1.20 & $<0.1$ & $<0.1$ & $<0.05$ & $<0.5$ & 2.00 & 4.00 & $<10$ & 1.50 & 0.20 & $<0.01$ & 6.99 & $<0.06$ \\
\hline & $3016^{\prime} 29.5^{\prime \prime} \mathrm{D}$ & Kaynağı & & & & & & & & & & & & & & & & \\
\hline \multirow{2}{*}{ K3 } & $3804^{\prime} 29.6^{\prime \prime} \mathrm{K}$ & Karakuyu & 2.00 & $<0.05$ & 0.40 & $<0.5$ & $<0.1$ & $<0.1$ & $<0.05$ & $<0.5$ & 2.00 & 3.60 & $<10$ & 1.40 & $<0.2$ & $<0.01$ & 7.04 & $<0.06$ \\
\hline & $3016^{\prime} 29.2^{\prime \prime} \mathrm{D}$ & Gölü & & & & & & & & & & & & & & & & \\
\hline \multirow[t]{2}{*}{ K4 } & $3804^{\prime} 29.9^{\prime \prime} \mathrm{K}$ & Karakuyu & 4.00 & 0.19 & 0.30 & 0.70 & 0.30 & $<0.1$ & $<0.05$ & $<0.5$ & 2.00 & 3.60 & $<10$ & 1.30 & $<0.2$ & $<0.01$ & 6.83 & $<0.06$ \\
\hline & $301624.4 " \mathrm{D}$ & Gölü & & & & & & & & & & & & & & & & \\
\hline \multirow[t]{2}{*}{ K5 } & $3804^{\prime} 28.9^{\prime \prime} \mathrm{K}$ & Karakuyu & 5.00 & 1.70 & 1.00 & 3.70 & 0.20 & $<0.1$ & $<0.05$ & $<0.5$ & 1.00 & 5.10 & $<10$ & 1.50 & 1.20 & $<0.01$ & 6.78 & $<0.06$ \\
\hline & 3016'17.9"D & Gölü & & & & & & & & & & & & & & & & \\
\hline \multirow[t]{2}{*}{ K6 } & $380427.9 " \mathrm{~K}$ & Karakuyu & 4.00 & 0.36 & 1.50 & 3.20 & 0.40 & $<0.1$ & $<0.05$ & $<0.5$ & 1.00 & 4.60 & $<10$ & 1.10 & 0.30 & $<0.01$ & 6.19 & $<0.06$ \\
\hline & $3016^{\prime} 14.5^{\prime \prime} \mathrm{D}$ & Gölü & & & & & & & & & & & & & & & & \\
\hline \multirow[t]{2}{*}{ K7 } & $3804^{\prime} 22.1^{\prime \prime} \mathrm{K}$ & Karakuyu & 3.00 & 0.41 & 0.60 & 2.10 & 0.20 & $<0.1$ & $<0.05$ & $<0.5$ & $<1$ & 4.40 & $<10$ & 1.40 & $<0.2$ & $<0.01$ & 6.52 & $<0.06$ \\
\hline & $3016^{\prime} 13.5^{\prime \prime} \mathrm{D}$ & Gölü & & & & & & & & & & & & & & & & \\
\hline \multirow[t]{2}{*}{ K8 } & $3804^{\prime} 21.5{ }^{\prime \prime K}$ & Karakuyu & 3.00 & 0.41 & 0.80 & 3.20 & 0.40 & $<0.1$ & $<0.05$ & $<0.5$ & 1.00 & 4.70 & $<10$ & 1.30 & $<0.2$ & $<0.01$ & 6.53 & $<0.06$ \\
\hline & 3016'08.1"D & Gölü & & & & & & & & & & & & & & & & \\
\hline \multirow[t]{2}{*}{ K9 } & $3804^{\prime} 12.3^{\prime \prime} \mathrm{K}$ & Karakuyu & 14.00 & 2.06 & 2.50 & 7.90 & 0.50 & $<0.1$ & $<0.05$ & $<0.5$ & 1.00 & 4.10 & $<10$ & 1.10 & 0.40 & $<0.01$ & 5.04 & $<0.06$ \\
\hline & $3015^{\prime} 33.9^{\prime \prime} \mathrm{D}$ & Gölü & & & & & & & & & & & & & & & & \\
\hline \multirow[t]{2}{*}{ K10 } & $3804^{\prime} 06.8{ }^{\prime \prime} \mathrm{K}$ & Karakuyu & 4.00 & 0.70 & 0.8 & 2.10 & $<0.1$ & $<0.1$ & $<0.05$ & $<0.5$ & 1.00 & 6.50 & $<10$ & 1.10 & $<0.2$ & $<0.01$ & 5.64 & $<0.06$ \\
\hline & $3015^{\prime} 44.4^{\prime \prime} \mathrm{D}$ & Gölü & & & & & & & & & & & & & & & & \\
\hline \multirow[t]{2}{*}{ K11 } & $3804^{\prime} 02.4^{\prime \prime} \mathrm{K}$ & Karakuyu & 25.00 & 106.70 & 1.30 & 4.70 & 0.10 & $<0.1$ & $<0.05$ & $<0.5$ & $<1$ & 3.10 & 126.00 & $<0.5$ & $<0.2$ & $<0.01$ & $<0.01$ & $<0.06$ \\
\hline & 3015'53.3"D & Gölü & & & & & & & & & & & & & & & & \\
\hline \multirow[t]{2}{*}{ K12 } & $380214.6 " \mathrm{~K}$ & Karakuyu & 27.00 & 37.96 & 1.90 & 8.40 & 0.30 & $<0.1$ & $<0.05$ & $<0.5$ & $<1$ & 2.30 & 87.00 & $<0.5$ & 0.50 & $<0.01$ & $<0.01$ & $<0.06$ \\
\hline & $3014^{\prime} 40.4^{\prime \prime} \mathrm{D}$ & Gölü & & & & & & & & & & & & & & & & \\
\hline \multirow[t]{2}{*}{ K13 } & $380258.1^{\prime \prime} \mathrm{K}$ & Karakuyu & 271.00 & 24.75 & 1.60 & 3.10 & 0.70 & $<0,1$ & $<0.05$ & $<0.5$ & $<1$ & 4.60 & 413.00 & 1.00 & 3.00 & $<0.01$ & 0.05 & $<0.06$ \\
\hline & $3013^{\prime} 48.5^{\prime \prime} \mathrm{D}$ & Gölü & & & & & & & & & & & & & & & & \\
\hline \multirow[t]{2}{*}{ K14 } & $380358.1 " \mathrm{~K}$ & Karakuyu & 24.00 & 14.33 & 0.70 & 1.90 & 0.20 & $<0.1$ & $<0.05$ & $<0.5$ & 1.00 & 4.20 & 55.00 & $<0.5$ & $<0.2$ & $<0.01$ & 0.54 & $<0.06$ \\
\hline & $3013^{\prime} 04.6^{\prime \prime} \mathrm{D}$ & Gölü & & & & & & & & & & & & & & & & \\
\hline \multirow[t]{2}{*}{ K15 } & $380436.6 " \mathrm{~K}$ & Karakuyu & 24.00 & 7.53 & 1.30 & 5.20 & 0.20 & $<0.1$ & $<0.05$ & $<0.5$ & $<1$ & 4.20 & 16.00 & $<0.5$ & $<0.2$ & $<0.01$ & $<0.01$ & $<0.06$ \\
\hline & 3015 37.1”D & Gölü & & & & & & & & & & & & & & & & \\
\hline \multicolumn{2}{|c|}{$\mathrm{TS}-266(2005) \mathrm{mg} / \mathrm{l}$} & & 0.20 & 0.05 & 2.00 & - & 0.01 & 0.00 & 0.01 & 0.01 & - & 0.01 & 0.20 & 0.05 & 0.02 & 0.50 & 50.00 & 0.50 \\
\hline \multicolumn{2}{|c|}{ WHO (2006) mg/l } & & 0.20 & 0.40 & 2.00 & - & 0.01 & 0.01 & 0.00 & 0.01 & - & 0.01 & & 0.05 & 0.07 & 0.20 & 50.00 & 1.50 \\
\hline
\end{tabular}


Tablo 5. Schoeller (1955) klorür, sülfat, karbonatbikarbonat sınıflaması

\begin{tabular}{|c|c|c|}
\hline \multirow{7}{*}{ 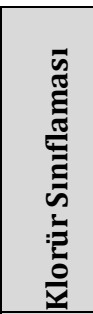 } & Su sinıfi & Klorür Miktarı (mek/l) \\
\hline & Hiperklorürlü Sular & $>700$ \\
\hline & Klorotalasik Sular & $420-700$ \\
\hline & $\begin{array}{l}\text { Klorürce Zengin } \\
\text { Sular }\end{array}$ & $140-420$ \\
\hline & Orta Klorürlü Sular & $40-140$ \\
\hline & Oligoklorürlü Sular & $15-40$ \\
\hline & Olağan Klorürlü Sular & $<15$ \\
\hline \multirow{5}{*}{ 竎 } & Su sinıfi & Sülfat Miktarı (mek/l) \\
\hline & Hiposülfatlı Sular & $>58$ \\
\hline & Sülfatlı Sular & $24-58$ \\
\hline & Oligosülfatlı Sular & $6-24$ \\
\hline & Olağan Sülfatlı Sular & $<6$ \\
\hline \multirow{4}{*}{ 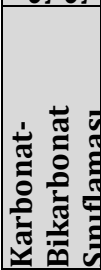 } & Su sinıfi & $\begin{array}{l}\text { Karbonat+Bikarbonat } \\
\text { Miktarı (mek/l) }\end{array}$ \\
\hline & $\begin{array}{l}\text { Hiperkarbonatlı } \\
\text { Sular }\end{array}$ & $>7$ \\
\hline & $\begin{array}{ll}\text { Olağan } & \text { Karbonatlı } \\
\text { Sular } & \\
\end{array}$ & $2-7$ \\
\hline & Hipokarbonatlı Sular & $<2$ \\
\hline
\end{tabular}

Çalışma alanından alınan su örneklerine ait analiz sonuçları Piper diyagramı üzerinde gösterilerek numunelerin hidrojeokimyasal fasiyesleri belirlenmiştir (SSekil 4). Buna göre su örnekleri Ca$\mathrm{CO}_{3}$ ve Ca-Mg-HCO ${ }_{3}{ }^{\prime \prime l}$ sular fasiyesinde yer almaktadırlar. Çalışma alanındaki su kaynakları genel olarak kireçtaşı ve dolomit gibi kalkerli kayaçlar ile etkileşim halindedir ve baskın su tiplerinin söz konusu kayaç-su etkileşimi sonucunda geliştiği görülmektedir.

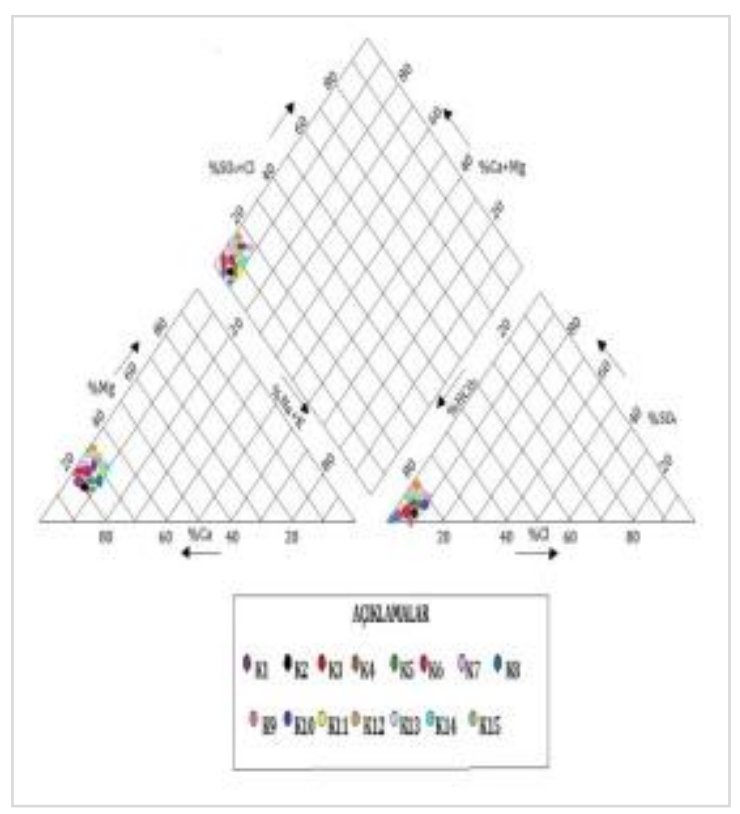

Şekil4.Piper diyagramı

Çalışma alanındaki su örneklerine ait anyon ve katyon analiz sonuçları Chadha diyagramı üzerine yerleştirildiğinde su örneklerinin $\mathrm{Ca}-\mathrm{Mg}-\mathrm{HCO}_{3}$ yapısında olduğu görülmektedir (Şekil 5). Bu durum, bölgedeki kalkerli kayaçların su kaynakları üzerindeki etkisini göstermektedir.

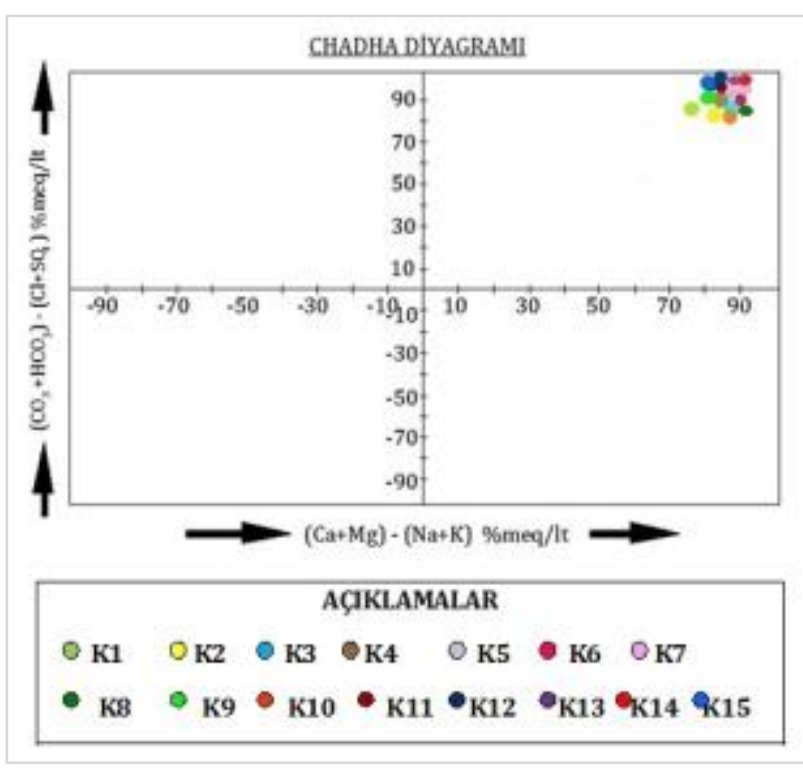

Şekil 5. Chadha diyagramı

Çalışma alanından su örneklerinin hangi işlev ve mekanizma sonucu değiştiğini belirleyebilmek için su örneklerinin TDS değeri ile $\mathrm{Na} /(\mathrm{Na}+\mathrm{Ca})$ oranları Gibbs diyagramı üzerine yerleştirilmiştir (Şekil 6). Gibbs diyagramı üzerinde su tiplerinin gelişmesinde etkin olan süreçlerden Evaporasyon/Kristalizasyon, Kayaç ve Atmosferik yağışın etkin olduğunu belirten 3 farklı alan tanımlanmıştır. Çalışma alanındaki su örneklerinin analiz sonuçlarına göre su örneklerinin tamamı 'Kayaç Baskın' bölgesinde yeralmakta ve suyun yapısındaki etkinin kayaç yapıcı minerallerin ayrışmasıyla oluştuğu görülmektedir.

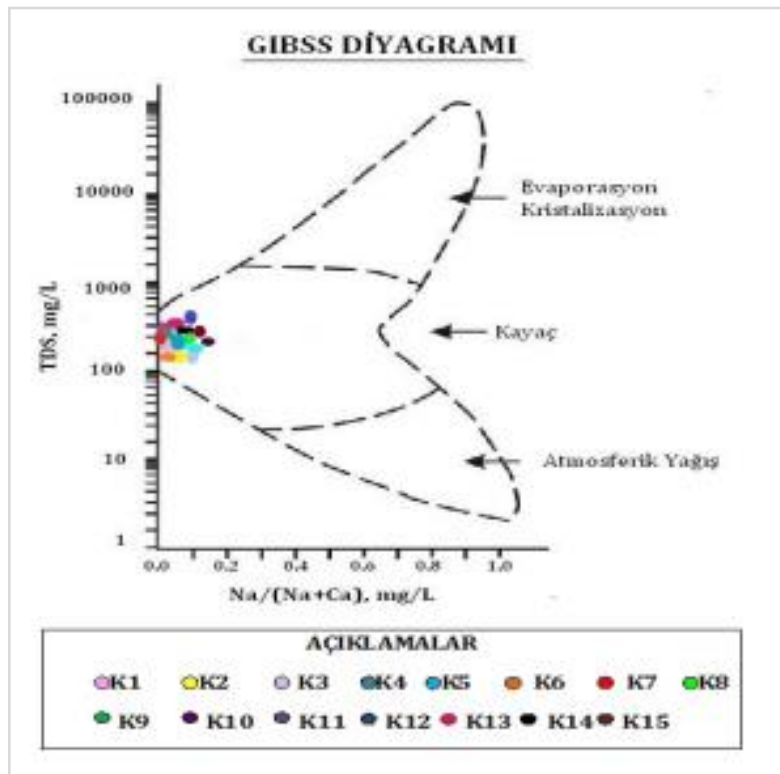

Şekil 4.3.Gibbs diyagramı

\subsection{Suların Kullanım ve Kalite Özellikleri}

Çalışma alanından alınan su örneklerinin kullanım özelliklerini değerlendirilmesinde öncelikle su 
örneklerinin analiz sonuçları TSE-266 (2005) ve Dünya Sağlık Örgütü (WHO, 2006) tarafından belirtilen içme suyu limit değerleri ile karşlaştırılmıştır. Buna göre K11 nolu su örneğinin Mn bakımından, K13 nolu su örneğinin ise $\mathrm{Al}$ ve $\mathrm{Fe}$ bakımından içme suyu olarak kullanıma uygun olmadığı, diğer su örneklerinin tamamının içme suyu standartları limit değerlerine göre içilebilir özellikte olduğu belirlenmiştir. Çalışma alanından alınan su örneklerinin analiz sonuçlarına göre hazırlanan H.Schoeller içilebilirlik diyagramına göre, su örneklerinin tamamı 'Íçilebilir Sular' sinıfında olup suların kalitesi 'Íyi-çok iyi kaliteli sular' sınıfına girmektedir (Şekil 7).

Sulama suyu olarak kullanım özelliklerinin değerlendirilebilmesi için su örneklerinin SAR (Sodyum Adsorbsiyon Oranı), \% Na, EC; RSC (Artıksal Sodyum Karbonat), MT (Magnezyum Tehlikesi), PI (Geçirgenlik İndeksi) ve KI (Kelley İndeksi) değerlerinin hesaplanmasının yanısıra ABD Tuzluluk laboratuvarı ve Wilcox diyagramları hazırlanmıştır.

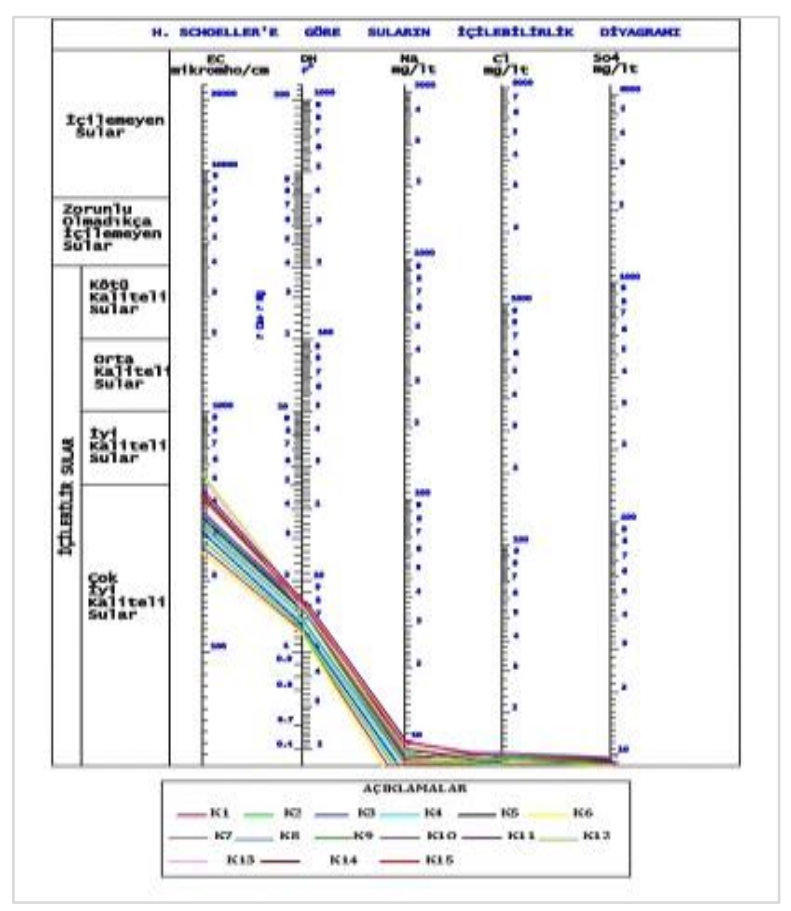

Şekil 7. H.Schoeller içilebilirlik diyagramı

Sular Sodyum Adsorbsiyon Oranlarına göre sulama suyu olarak kullanılabilirliği açısından dört sınıfa ayrılmıştır (Tablo 6). Çalışma alanındaki suların analiz sonuçları kullanılarak hesaplanan SAR değerleri genel olarak 0.09 -0.13 arasında değișmekte olup 'çok iyi özellikte sulama suları' sınıfına girmektedir. \% $\mathrm{Na}$ değerine göre sulama suyu sınıfları Tablo 7'de verilmiş olup, çalışma alanındaki su örneklerinin tamamı 'çok iyi' sulama suyu sınıfindadır.
Sulama sularının kalitesinin belirlenmesinde, suların içerisindeki çözünebilen tuzların toplam konsantrasyonları dikkate alınarak sular özgül elektriksel iletkenliği açısından sınıflandırılmıştır.

Tablo 6. SAR' a göre sulama suyu sınıflaması (Richards (1954)

\begin{tabular}{|c|c|}
\hline SAR \% & Sulama suyu sınıfı \\
\hline$<10$ & Çok iyi özellikte sulama suları \\
\hline $10-18$ & İyi özellikte sulama suları \\
\hline $18-26$ & Orta özellikte sulama suları \\
\hline$>26$ & Kötü özellikte sulama suları \\
\hline
\end{tabular}

Tablo 7. \% $\mathrm{Na}^{\prime}$ a göre sulama suyu sinıflaması (Wilcox 1955)

\begin{tabular}{|c|c|}
\hline \% Na & Sulama suyu sınıfı \\
\hline $0-20$ & Çok İyi \\
\hline $20-40$ & İyi \\
\hline $40-60$ & İzin verilebilir \\
\hline $60-80$ & Şüpheli \\
\hline$>80$ & Uygun değil \\
\hline
\end{tabular}

Suların toplam tuz içeriğinin Ayers ve Westcost (1989)'a göre sinıflaması verilmiştir (Tablo 8). Çalışma alanından alınan su numunelerinin özgül elektriksel iletkenlik değerleri yerinde ölçümlere göre 347-521 $\mu \mathrm{mho} / \mathrm{cm}$ arasında değişmektedir. Buna göre suların tamamı orta tuzlu sular sinıfinda olup yıkama ile sulamada kullanılabilir özelliktedir

Tablo 8. Suların toplam tuz içeriğine göre sınıflaması (Bauder 2011)

\begin{tabular}{|c|c|c|}
\hline Sınıf & EC & Açıklama \\
\hline $\begin{array}{c}\text { Düşük Tuzlu } \\
\text { Sular }\end{array}$ & $<250$ & $\begin{array}{c}\text { Sulamada kullanılan } \\
\text { en uygun sular }\end{array}$ \\
\hline $\begin{array}{c}\text { Orta Tuzlu } \\
\text { Sular }\end{array}$ & $250-750$ & $\begin{array}{c}\text { Ylkama ile sulamada } \\
\text { kullanılabilir }\end{array}$ \\
\hline $\begin{array}{c}\text { Yüksek Tuzlu } \\
\text { Sular }\end{array}$ & $750-2250$ & $\begin{array}{c}\text { Tuza dayanıklı bitki } \\
\text { yetiștirmede }\end{array}$ \\
\hline $\begin{array}{c}\text { Çok Yüksek } \\
\text { Tuzlu Sular }\end{array}$ & $>2250$ & $\begin{array}{c}\text { Sulamada } \\
\text { kullanıllmaz }\end{array}$ \\
\hline
\end{tabular}

Tarımsal amaçlı kullanılan sularda karbonat ve bikarbonat içeriğinin zararlı etkisini belirlemek için Artıksal Sodyum Karbonat (RSC) değeri kullanılmaktadır (Eaton, 1950). RSC değeri 2.5'den büyük ise sulamaya uygun değil, 1.25 ile 2.5 arasında ise 'şüpheli', 1.25 'den küçük ise 'iyi' sulama suyu sinıfındadır (Eaton, 1950). İnceleme alanındaki su örneklerinin RSC değerleri-0,49 ile 0,19 mek/l arasında değişmekte olup 'iyi' sulama suyu sınıfında yer almaktadır.

Suların $\mathrm{Na}, \mathrm{Ca}, \mathrm{Mg}$ ve $\mathrm{HCO}_{3}$ değerlerini kullanarak hesaplanan PI değerine göre sulama suyu sınıflandırması Tablo 9'da verilmiştir. Çalışma 
alanında bulunan su örneklerine ait PI değerleri \% 39,51 ile \% 51,89 arasında değişmekte olup su sınıfının 'Sınıf II' kategorisinde olduğu görülmektedir

Tablo 9. PI'ye göre sulama suyu sinıflaması (Raghunath 1987)

\begin{tabular}{|c|c|}
\hline PI & Sulama suyu sınıfı \\
\hline$>\% 75$ & Çok İyi \\
\hline$\% 75-\% 25$ & İyi \\
\hline$<\% 25$ & Uygun değil \\
\hline
\end{tabular}

Sulama suyunda magnezyum iyonunun fazlalığ toprak alkalitesini arttırarak kalitesinin bozmakta ve ürün verimini olumsuz yönde etkilemektedir. Mg ve Ca iyon miktarları dikkate alınarak hesaplanan MT değeri 50'den küçük ise sulama suyu olarak kullanıma uygun, 50'den büyük ise uygun değildir. Su örneklerinin hesaplanan MT değerleri \% 23,75-\% 27,24 arasında değişmektedir. Buna göre sular sulama suyu olarak kullanıma uygundur.

Suların sulamada kullanılabilirliğini belirlemek için kullanılan diğer önemli bir parametre olan Kelley İndeksi (KI) ise $\mathrm{Na}$, Ca ve $\mathrm{Mg}$ iyonlarını dikkate alarak hesaplanmaktadır. İnceleme alanından alınan suların KI değerleri 0,028-0,044 mek/l arasında değişmekte olup sulama suyu olarak 'uygun' sinifinda bulunmuştur (Tablo 10).

Tablo 10. KI’ya göre sulama suyu sinıflaması (Kelley 1940)

\begin{tabular}{|c|c|}
\hline KI & Sulama suyu sınıfı \\
\hline$<1$ & Uygun \\
\hline $1-2$ & Kısmen uygun \\
\hline$>2$ & Uygun değil \\
\hline
\end{tabular}

ABD Tuzluluk Laboratuvarı diyagramına göre sular 'C2S1' sular sınıfında yer almaktadır (Şekil 8). Bu sinıflamaya göre sular orta derecede tuza ihtiyacı olan bitkiler için kullanılabilen orta tuzlulukta su ve sodyuma karşı duyarlı olan bitkiler dışında her türlü tarım için uygun olan az sodyumlu su özelliğindedir. Wilcox diyagramına göre ise suların "çok iyi kullanılabilir" sular olduğu belirlenmiştir (Şekil 9). Bu sonuçlar çalışma alanı ve yakın çevresindeki suların genel anlamda tüm sulama faaliyetlerinde kullanılabilecek özellikte sular olduğunu göstermektedir.

Çalışma alanındaki suların kalite sınıflandırılmasında Su Kirliliği Kontrol Yönetmeliği (Anonim, 2004)'nde belirlenen Kıta İçi Su Kaynaklarının Sınıflarına Göre Kalite Kriterlerine ait limit değerler kullanılmıştır. Çalışma alanındaki su örneklerine ait analiz sonuçları kalite kriterleri ile karşılaştırıldığında su örneklerinin genel olarak birçok parametre bakımından I. Su kalite sınıfında olduğu görülmektedir. Sadece K11 nolu su örneğinin Mn parametresi bakımından, K13 nolu su örneğinin ise Fe parametresi bakımından II. su kalite sınıfında yeraldığı belirlenmiştir. Bu parametrelerin su örneklerinde kısmen yüksek oranlarda ölçülmüş olması bölgedeki litolojik birimler ile kayaç-su etkileşiminin bir sonucudur.

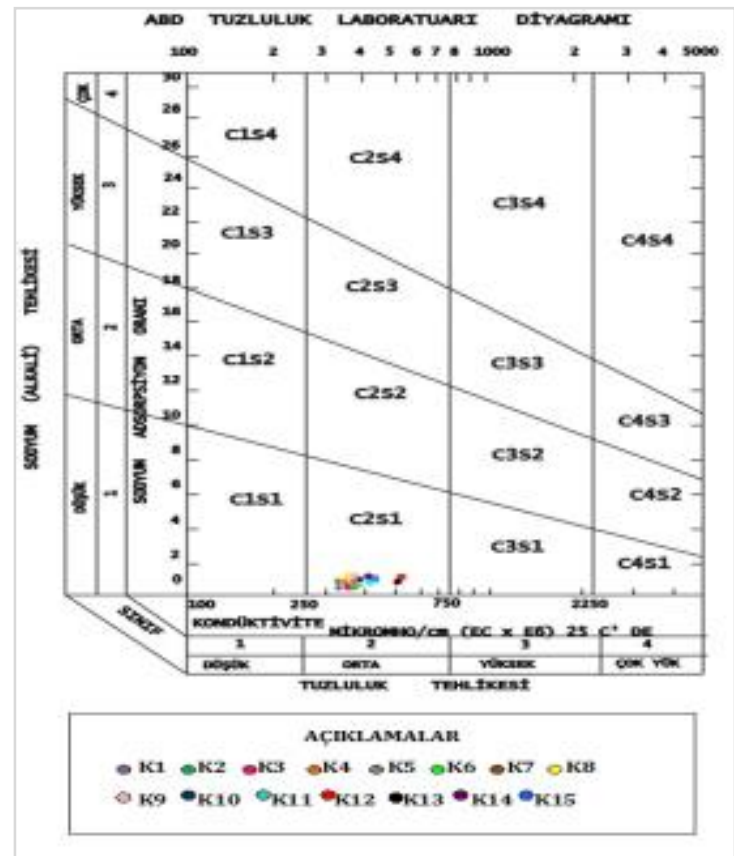

Şekil 8. ABD tuzluluk laboratuvarı diyagramı

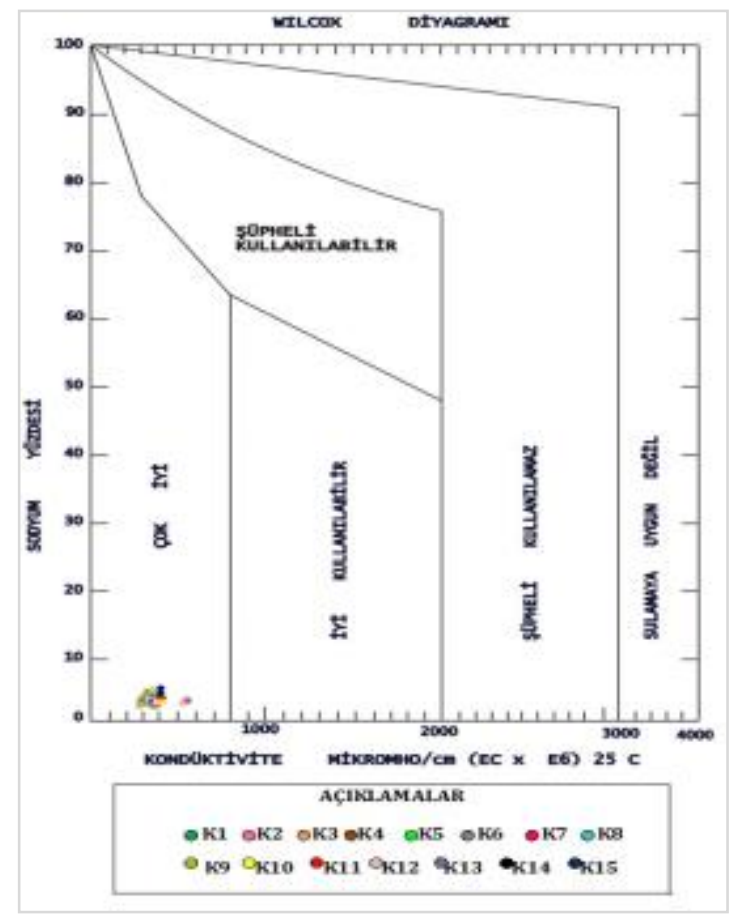

Şekil 9. Wilcox diyagramı

\section{Sonuçlar}

$\mathrm{Bu}$ çalışmada, Karakuyu Gölü sulak alanı ve çevresinin hidrojeolojik ve hidrojeokimyasal incelemeleri yapılarak yeraltısuyu seviyesi ve dinamiği ile birlikte su kaynaklarının iyon özellikleri, kullanım durumları ve kirlilik değerlendirmeleri 
yapılmıștır. Sulak alanın beslenmesini sağlayan başlıca yüzey suları Kirazlı Dere, Çakalboğazı Dere, Kumalar Çayı, Bucak Dere, Güdül Dere ve Çay Deresidir. Gölü ve sulak alanı besleyen en önemli kaynak boşalımı ise gölün güneydoğusundaki karstik kireçtaşlarından boşalan Eldere (Kocapınar, Pınarbaşı, Ulupınar) kaynağı'dır. Ayrıca, Eldere kaynağının kuzey-kuzeybatısında grup kaynaklar olarak aynı karstik kireçtaşlarından boşalan Burunkaya kaynakları bulunmaktadır. Bölgede yüzeyleyen jeolojik birimler akifer olabilme potansiyellerine göre Akifer-1, Akifer-2, Akitard ve Akifüj olmak üzere dört ayrı grupta incelenmiștir. Çalışma alanında bulunan yeraltısuyu kuyularının tamamı ovada alüvyon birim üzerinde açılmıştır. Ancak, Çapalı ve Burunkaya mevkilerinde bulunan kuyularda alüvyon ile birlikte kireçtaşı birimlerinden de yeraltısuyu alınmaktadır. Bölgede yeraltısuyu derinliği $0 \mathrm{~m}-15,15 \mathrm{~m}$. arasındadır. Hazırlanan yeraltısuyu seviye haritası üzerindeki yeraltısuyu seviye eğrileri incelendiğinde, yeraltısuyu yüzeyinin morfolojisinin düzgün olduğu görülmektedir. Bölgede yeraltısuyu akımının gölün kuzeyinde güneye doğru, gölün güneyinde ise kuzey-kuzeybatıya doğru olmak üzere Karakuyu Gölü’ne doğru olduğu görülmektedir.

Çalışma alanındaki yüzey sularının iyon özelliklerinin belirlenmesi amaciyla; sertlik, hidrojen iyonu konsantrasyonu $(\mathrm{pH})$, özgül elektriksel iletkenlik (EC), sodyum adsorbsiyon oranı (SAR) ve sodyum iyon yüzdesi (\% Na), aynı zamanda suların Piper, Gibbs ve Chadha diyagramları kullanılarak su örneklerinin özellikleri değerlendirilmiştir. Piper diyagramına göre su örneklerinin tamamı Ca- $\mathrm{HCO}_{3}$ ve Ca-Mg- $\mathrm{HCO}_{3}{ }^{\prime}$ lü sular fasiyesindedir. Aynı şekilde, Chadha diyagramına göre de su numunelerinin tamamı Ca-Mg- $\mathrm{HCO}_{3}$ su tipini yansıtmaktadır. Gibbs Diyagramına göre ise su örnekleri 'Kayaç Baskın' bölgesinde yeralmaktadır.

Kullanım özellikleri bakımından incelendiğinde su örnekleri genel olarak sulama ve içme suyu olarak kullanıma uygundur. Ancak, TSE-266 ve WHO tarafından belirtilen içme suyu limit değerlerine göre K11 nolu su örneğinin Mn bakımından, K13 nolu su örneğinin ise $\mathrm{Al}$ ve Fe bakımından içme suyu olarak kullanıma uygun olmadığı, belirlenmiştir. Ayrıca, suların kalite sinıflamasinda kullanılan limit değerlere göre su örneklerinin tamamı I. Su kalite sınıfındadır. Sadece K11 nolu su örneğinin Mn parametresi bakımından, K13 nolu su örneğinin ise Fe parametresi bakımından II. su kalite sınıfında yeralmaktadir.

Elde edilen tüm veriler birlikte değerlendirildiğinde su örneklerinin genel olarak kalite açısından iyi durumda olduğu ve özellikle sulama suyu olarak kullanıma uygun olduğu görülmektedir. Hakim su tiplerinin ise tamamen bölgede yüzeyleyen kalkerli kayaçlar ile ilişkili olarak kayaç-su etkileşim süreçlerinin

etkisinde

geliştiğini

söylemek

mümkündür.

\section{Teşekkür}

$\mathrm{Bu}$ çalışma Süleyman Demirel Üniversitesi Bilimsel Araştırma Projeleri Koordinasyon Birimi tarafından 4317-YL1-15nolu proje kapsamında desteklenmiştir. Yazarlar, çalışmayı finansal olarak destekleyen SDÜ Bilimsel Araștırma Projeleri Yönetim Birimi Başkanlı̆̆ı'na teşekkür ederler.

\section{Conflict of Interest / Çıkar Çatışması}

Yazar tarafından herhangi bir çıkar çatışması beyan edilmemiştir.

No conflict of interest was declared by the author.

\section{Kaynaklar}

Anonim, 2004. Su Kirliliği ve Kontrol Yönetmeliği, Resmi Gazete, Sayısı, 25687.

Ayers, R.S.,Westcot, D.W., 1985. Water quality for agriculture, FAO Irrigation and drainage Paper No. 29, Rev. 1, U.N. Food and Agriculture Organization, Rome

Balcl, V., 2011. 1/100.000 ölçekli Türkiye Jeoloji Haritaları No 162 Afyon-L 24 Paftası MTA Jeoloji Etütleri Dairesi Ankara

Bauder, T.A., Waskom, R.M., Davis, J.G., Sutherland, P.L., 2011. Irrigation water quality criteria. Fort Collins, CO: Colorado State University Extension.

Bulut, İ., Karapınar, B., Özoğul B., 2016. Karakuyu Gölü (Afyonkarahisar-Dinar) ve Yüzen Adaları, TÜCAUM Uluslararası Coğrafya Sempozyumu Ankara.

Chadha, D.K., 1999. A Proposed New Diagram For Geochemical Classification of Natural Water sand Interpretation of Chemical Data. Hdrogeology Journal, 7, 431-439.

Eaton, F.M., 1950. Significance of carbonate in irrigationwater. SoilSci 69 (2):123-133.

Ersoy, Ş., 1989. Fethiye (Muğla)-Gölhisar (Burdur) arasında Güney Dağı ile Kelebekli Dağı ve dolayının jeolojisi. Doktora Tezi, İstanbul Üniversitesi Fen Bilimleri Enstitüsü, 246s.

Fugro Sial., 2014. Yukarı Menderes Havzası (Küfi) Yeraltısuyu Planlama Hidrojeolojik Etüd Raporu. 474 s.

Gibbs, R., 1970. Mechanism Controlling World River Water Chemistry. Science 170,1088-1090.

Güney, B., 2014. Havza Yönetim Planları İçerisinde 
Sulak Alanların Yeri, Kuş ve Habitat Direktifleriyle Olan İlişkisi, Orman ve Su İşleri Bakanlığl, Su Yönetimi Genel Müdürlüğü, Uzmanlık Tezi, 184 s. Ankara.

Kelley, W.P., 1940. Permissible composition and concentration of irrigation waters. In: Proceeding American Society of Civil Engineering, $607 \mathrm{p}$.

Özdemir, M.A. ve Gür, E., 2016. Dinar Depremi Öncesinde ve Sonrasında Dinar Şehri ve Yakın Çevresinde Arazi Kullanımı, TÜCAUM Uluslararası Coğrafya Sempozyumu Ankara.

Öztürk, E.M. ve Öztürk, Z. 1989. Balçıhisar-Karaadilli (Afyon) Dereköy (Isparta) dolayının jeolojisi. Maden Tetkik ve Arama Genel Müdürlüğü Raporu 8946 (yayımlanmamış).

Piper, A.M., 1944. A Graphic Procedure in Geochemical Interpretation of Water Analyses, American Geophysical Union Transactions 25, 914-923.

Polat, S., Güney Y., Deniz M., 2011. Karakuyu Gölü Sulak Alanı ve Başlıca Problemleri, Uluslararası Katılımlı Coğrafya Kongresi 2011, 07-10 Eylül 2011, 450-467s., İstanbul.

Ramsar, 1971. Convention on Wetlands of International Importance Especially as Waterfowl Habitat, Ramsar, Iran.

Raghunath, H.M., 1987. Groundwater, 2nd edn. Wiley Eastern Ltd, New Delhi 563p

Richards, L.A., 1954. Diagnosis and improvement of saline and alkali soils. USDA Agricultural Handbook No. 60. US Department of Agriculture, Washington DC, p 160.

Schoeller, H., 1955. GechemieDesEauxSouterranes. ReviewInstutieFranc. Petrole, Paris, 3-4.

Şenel, M., H., Bilgin, Z.R., Şen, A.M., Karaman, T., Dinçer, M.A., Durukan, E., Arbas, A., Örçen, S. Ve Bilgi C. 1989. Çameli (Denizli)-Yeşilova (Burdur)Elmalı (Antalya) ve kuzeyinin jeolojisi. Maden Tetkik ve Arama Genel Müdürlüğü Rapor No: 9761, Ankara ( yayımlanmamış).

Şenel, M. 1997. 1/100.000 ölçekli Türkiye Jeoloji Haritalarl, Isparta J11 paftası. MTA Genel Müdürlüğü, jeoloji Etütleri Dairesi yayını, Ankara.

Şahinci, A., 1991. Doğal Suların Jeokimyası. Reform Matbaası, 548s, İzmir.

TS-266, 2005. Sular - İnsani tüketim amaçlı sular, TS266, Türk Standartları Enstitüsü, 25 s, Ankara.

WHO 2006. World Health Organisation Guidelines for drinking water quality, First addendum to third edition, vol. 1, Recommendations, WHO Publication, Geneva, 494 p. 2006.

Wilcox, L.V., 1955. Classification and use of irrigation water. USDA, Circular, Washington. 